Article

\title{
Energy Vision Strategies for the EU Green New Deal: A Case Study of European Cities
}

\author{
David Maya-Drysdale ${ }^{1, * \mathbb{D}}$, Louise Krog Jensen ${ }^{2}$ and Brian Vad Mathiesen ${ }^{1}$ \\ 1 Department of Planning, Aalborg University, A. C. Meyers Vænge 15, 2450 Copenhagen, Denmark; \\ bvm@plan.aau.dk \\ 2 Department of Planning, Aalborg University, Rendsburggade 14, 9000 Aalborg, Denmark; \\ louise@plan.aau.dk \\ * Correspondence: drysdale@plan.aau.dk; Tel.: +45-25700117
}

Received: 6 April 2020; Accepted: 24 April 2020; Published: 2 May 2020

\begin{abstract}
There are three strategic levels for successful energy planning in cities: 1) Integration strategy for integrating energy planning into urban planning institutions; 2) Practice strategy for developing suitable energy planning practices in urban planning institutions, and 3) Vision strategy for the creation and integration of energy visions and scenarios required for long-term decarbonisation. The vision strategy is critical but not well researched and is the focus of this article. Using Strategic Energy Planning (SEP) as an analytical framework, the vision strategy of eight forerunner European cities are analysed. Some critical elements of SEP include the use of long-term targets, holistic energy system thinking, and retention of scenarios. The results indicate that the level of understanding and practice of the vision strategy is still deficient in the cities. Cities often use the practice of urban planning, which does not fit very well with energy planning, particularly with the vision strategy. The energy planning in the cities mostly focuses on shorter-term goals and actions, and they often abandon energy scenarios once extracted. However, through trial and error, some cities are finding ways forward. The article concludes with several recommendations, particularly that cities need to see scenarios as retainable long-term servants providing information desired by the planner, rather than serving as a guide to the planner.
\end{abstract}

Keywords: climate change; strategic energy planning; city; decarbonisation

\section{Introduction}

The EU aims to be climate neutral by 2050, which is at the heart of the Green New Deal and written into the Climate Law [1]. The role of cities needs to be enhanced to achieve this goal so that they can contribute effectively [2]. Local initiatives in cities are important in achieving overall national and international goals since most energy technologies have a regional planning element in distributed energy systems [3].

Climate change has been a focus for cities for many years [4], particularly addressing challenges to institutionalise it in planning practice [5-7]. The focus on climate change within urban planning involves Energy Planning, defined by [8] as "determining the optimal mix of energy sources to satisfy a given energy demand." Optimality considers multiple criteria for decision making, including the traditional multiple scales (temporal and geographical) and quantitative technical and economic criteria [8]. Energy planning in the climate change context relates to the measures and actions of a city and their qualitative environmental impact and social criteria that lead to a decarbonised energy system.

Energy planning has been practiced by urban planners in Europe for a shorter period than climate change since energy is not traditionally under their authority $[9,10]$, with some exceptions, such as the Danish heat planning law and Swedish energy planning law. Recently, cities are setting 
ambitious energy decarbonisation goals (for example, Copenhagen, Hamburg, Frankfurt aiming for $100 \%$ renewable energy by 2050) [11]. Cities are also joining city energy networks to share knowledge and develop methods [12], joining EU energy projects [13], and engaging local stakeholders in their local energy measures [14]. Furthermore, countries have set low carbon goals [15] (for example, Denmark and Sweden aiming for 100\% renewable energy by 2050 and 2045, respectively), which will help cities achieve their goals by decarbonising the electricity grid that electrifies them [16].

This article argues that there are three primary strategic levels to achieve successful energy planning in cities. Although, there is no predefined order since cities can operationalise them independently, and they all constantly interact. The first level is about integrating the practice of energy planning as an institutionalised strategic practice in planning departments, with a particular focus on building legitimacy [6]. The second level is about developing sufficient energy planning practices in urban planning, for example, through Integrated Energy Planning [17], involving implementation and collaboration with stakeholders. Efforts have focused on teaching energy planning to urban planners [18]. The third strategic level of energy planning is about developing strategic visions and scenarios for a decarbonised energy system and making appropriate plans towards this $[17,19]$. This level is herein called the vision strategy and is the focus of this article.

For energy planning for decarbonisation to emerge, we regard the Vision strategy highly essential. The Covenant of Mayors Sustainable Energy Action Plan (SEAP) is a successful, although limited, approach cities have used to address the vision strategy $[2,7,20,21]$. In Europe, the SEAP approach helps cities in their ambitions towards the EU 2020 and 2030 targets, and involves city diagnosis (baseline emissions) and identifying measures to address emissions to meet specific $\mathrm{CO}_{2}$ goals. The approach clarifies the local energy problems, using energy visions and scenarios to help identify potential solutions [22]. However, we argue that the vision strategy needs to be more advanced and based on some key Strategic Energy Planning (SEP) elements, including long-term decarbonisation targets, holistic energy system thinking, and retention of energy scenarios.

\subsection{Aim of This Article}

This article aims to analyse which strategic practices forerunner European cities currently employ to promote decarbonisation in energy planning. The article analyses how eight European forerunner cities are addressing the vision strategy in terms of the creation and integration of decarbonisation visions and scenarios. The energy planning practices of each city are analysed via an analytical framework based on SEP, as described in [23].

The cities are chosen based on their ambition for achieving decarbonisation in the future. Each of the eight European cities is analysed and evaluated regarding the manner that each city addresses the strategic level to:

- Understand the basic energy planning practices

- Understand how the cities plan, create and integrate decarbonisation visions and scenarios

- Overall evaluate the Vision strategy in each city

This article uses the term city broadly to include subnational areas, which may include municipalities, small regions, villages, towns, or cities.

\subsection{Structure of the Article}

Section 2 describes the method, which involves interviews and desktop research, and the analytical framework to analyse the cities. This section also describes the strategic levels of energy planning, emphasising the role of creating and integrating decarbonisation visions and scenarios.

Section 3 presents the results for the cities concerning some critical themes related to the vision strategy of energy planning in the cities.

Section 4 discusses the results in the context of the vision strategy.

Section 5 presents some conclusions for future energy planning in cities. 


\section{Methodology}

The study selected eight diverse forerunner cities from Europe that have demonstrated ambition and progress regarding energy planning and decarbonisation. For each city, the energy planning vision strategy is evaluated based on a framework described in this section. The interviews contained questions based on the analytical framework.

\subsection{Strategic Levels of Energy Planning in Urban Planning}

Decarbonisation of the energy system involves developing a highly interconnected energy system that is more efficient, cost-effective, and with minimal (imported) biogenic resource demands [24-26]. Such integrated systems have been researched in recent years, for example, in Denmark for $100 \%$ renewable energy (Figure 1).

(a)

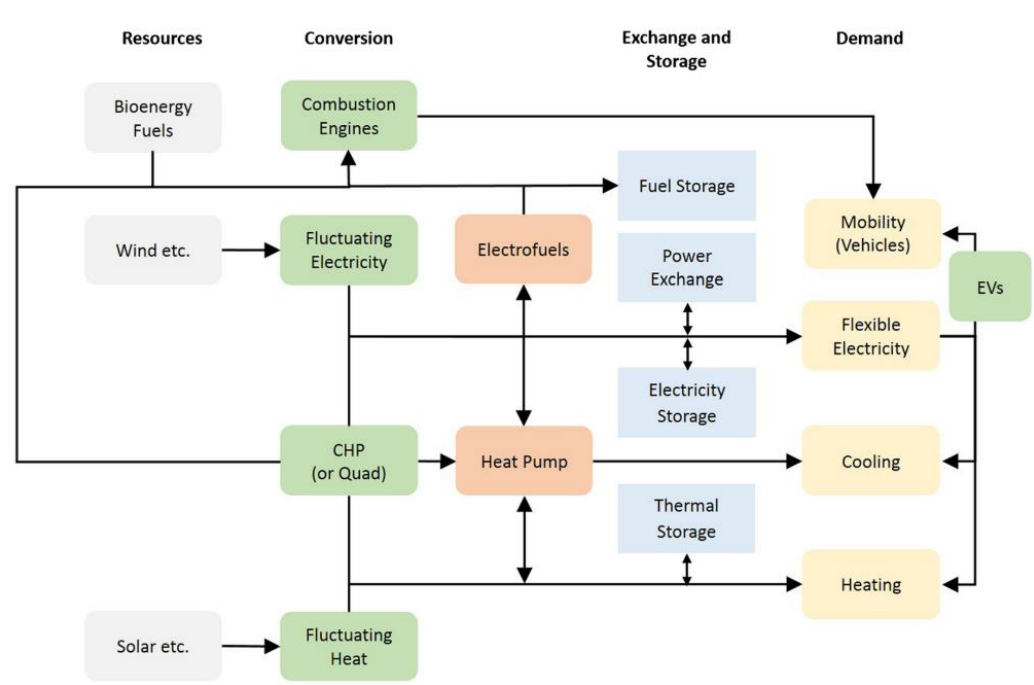

(b)

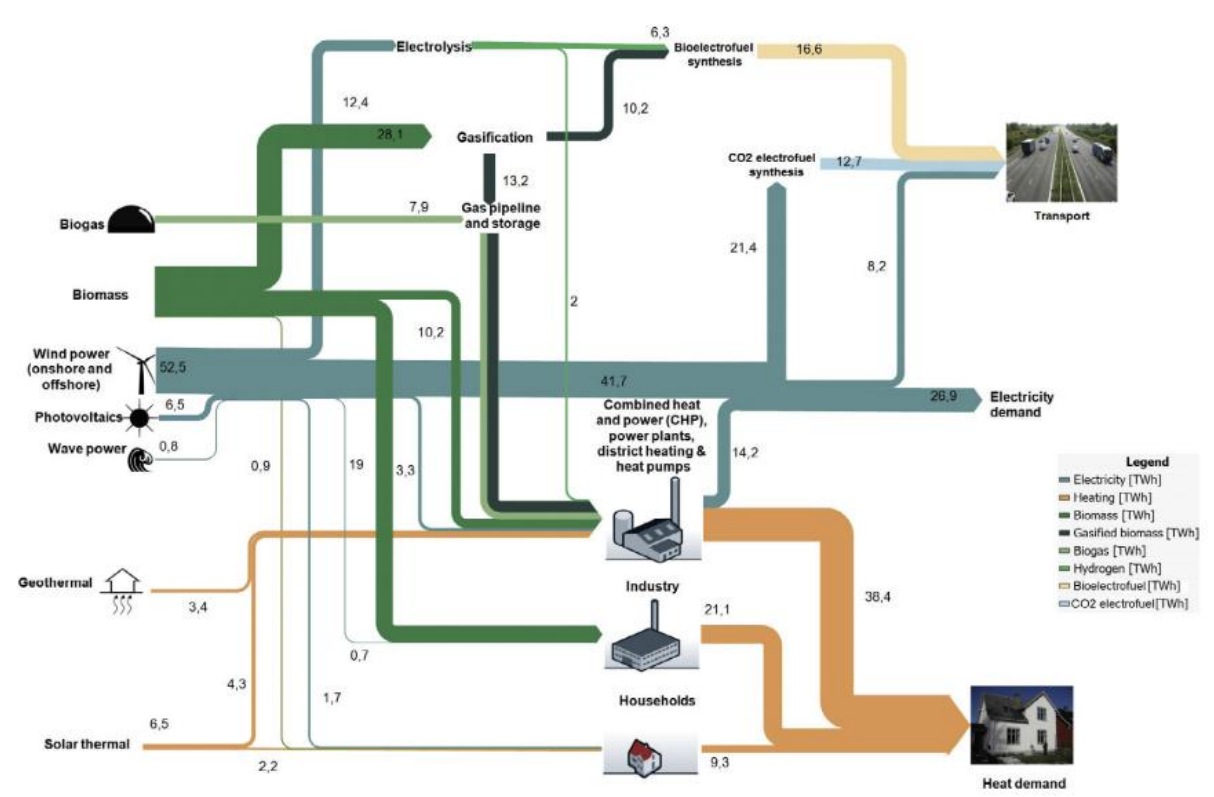

Figure 1. (a) Interconnected renewable energy system components [27] and (b) efficient energy flows [26]. 
At a planning level, the transition to a sustainable energy system involves a complex mix of agents (stakeholders), objects (technologies and infrastructures), and the environment [28]. The environment provides resources but also sets the conditions for the energy system socially, politically, and culturally. The new energy infrastructure regime will likely emerge as Bulkeley ([5], p.1477) states as a "configuration alongside and in-between the existing socio-technical systems" [5]. The energy system adapts in a self-organised emergent behavior of the agents and objects of the system [28]. Strategies could include and empower numerous actors and stakeholders in strategic thinking and strategic architecture rather than rational strategic plans [29], forming meta-governance arrangements that have emerged in recent years [30]. A meta-governance arrangement develops where the institutions influence the interaction of agents through networks $[28,30]$. These complex elements bring a new set of wicked problem conditions into the urban and energy planning practice. Including a "lack of a single problem statement", "conflicting values", and "conflicting objectives", to name a few [10]. Furthermore, the complex adaptive energy system lends itself to scenario models that are good at prediction and forecasting [28].

Stabilising a new decarbonisation regime could emerge through the (re)alignment of discourses, actors, institutions, techniques, and artefacts [5], with the three critical strategic elements being institutions, techniques, and artefacts [31]. Discourses and actors are essential to the regime change and play a role in vision and scenario creation, thus strongly linking to the artefacts.

This article proposes that these three elements require three levels and practices of strategy. Cities develop strategies independently for each level, although they are all interrelated, and there is no predefined order. Over the last decades, the concept of sustainable development has slowly struggled and emerged within urban planning via strategic actions at levels one and two [32-35].

Strategic level 1. Institutions (integration strategy). Strategic level one relates to addressing political buy-in and aligning internal departments and resources to ensure sufficient energy planning. Often, city administrations divide into silos with limited cross-sectoral coordination, and practices lack standardisation [36,37]. Furthermore, crucial sectors related to greenhouse gas emissions are not within the influence or responsibility of cities since they often focus on other issues such as land-use planning [4].

Strategic level 2. Techniques (practice strategy). Strategic level two is about developing and improving energy planning know-how (i.e., practices, skills, competences, and expertise) to ensure sufficient energy planning. Researchers have proposed methods, such as Integrated Energy Planning [38] involving stakeholders and creating discourses through visions and scenarios, as well as implementing energy plans.

Strategic level 3. Artefacts (vision strategy). Strategic level three is related to developing appropriate visions, scenarios, and reports and plans to ensure sufficient energy planning. This strategy comes from the fact that cities often focus on individual initiatives that are small-scale, creating disproportionate system effects [39]. Energy planning needs to have clear long-term goals, clear vision, scenario creation within a strategic order, and involve the right stakeholders in the municipality, which is a rather new and unknown territory in most cities.

Strategic visions and scenarios can provide insight into the decarbonisation of energy systems, especially system integration in cities. This article focuses on the decarbonised energy system and its requirements and what planners need to do in response to this, often referred to as backcasting [34,40], as opposed to what planners are doing to integrate energy planning into their practices. The Vision strategy requires a mix of rational strategic planning (to understand the interconnected energy system) and stakeholder engagement (to provide local knowledge and partnerships for implementing the interconnected energy system). This article does not interpret the results for the first and second strategic levels, although these have been researched previously $[5,6,41]$. 


\subsection{Making a Case for a Vision Strategy in Energy Planning}

Cities are centres of high energy demand and have great potential to reduce this demand. A recent study extrapolated Covenant of Mayors individual trajectories to 2050 and indicated that they are on track to meet the central aim of the Paris Agreement-the pursuit to limit global temperature rise of $1.5^{\circ} \mathrm{C}$ above pre-industrial levels this century [20]. However, the challenge is that when emission reductions increase, as renewable energy increases on a large-scale, the energy system has new integration challenges [42]. Technologies in the renewable system will be interconnected and interactive [24,42], involving process enhancements, efficiency increase, system integration, and multigeneration [43]. The behavioral change will also be a significant contributor [44]. Combined, this has implications for local energy planning for planning new infrastructures and integrating them. Studies that extrapolate to 2050 preclude identifying and understanding these integration challenges and opportunities.

\subsubsection{From Silo to Energy Systems}

As the energy system becomes more integrated and decarbonised, the extent of the vision strategy increases (Figure 2). Planning shifts from not only basic non-concrete statements or silo-thinking about site or plant level efforts, such as the need for renewable energy measures, but to advanced system-level thinking considering the need for system integration, or sector coupling. The basic level is still there and essential: cities will always need to implement projects one-by-one. But on top of this, the bigger picture has changed and is getting more complicated-requiring systems-level thinking. For example, understanding the import and export of energy between sectors.

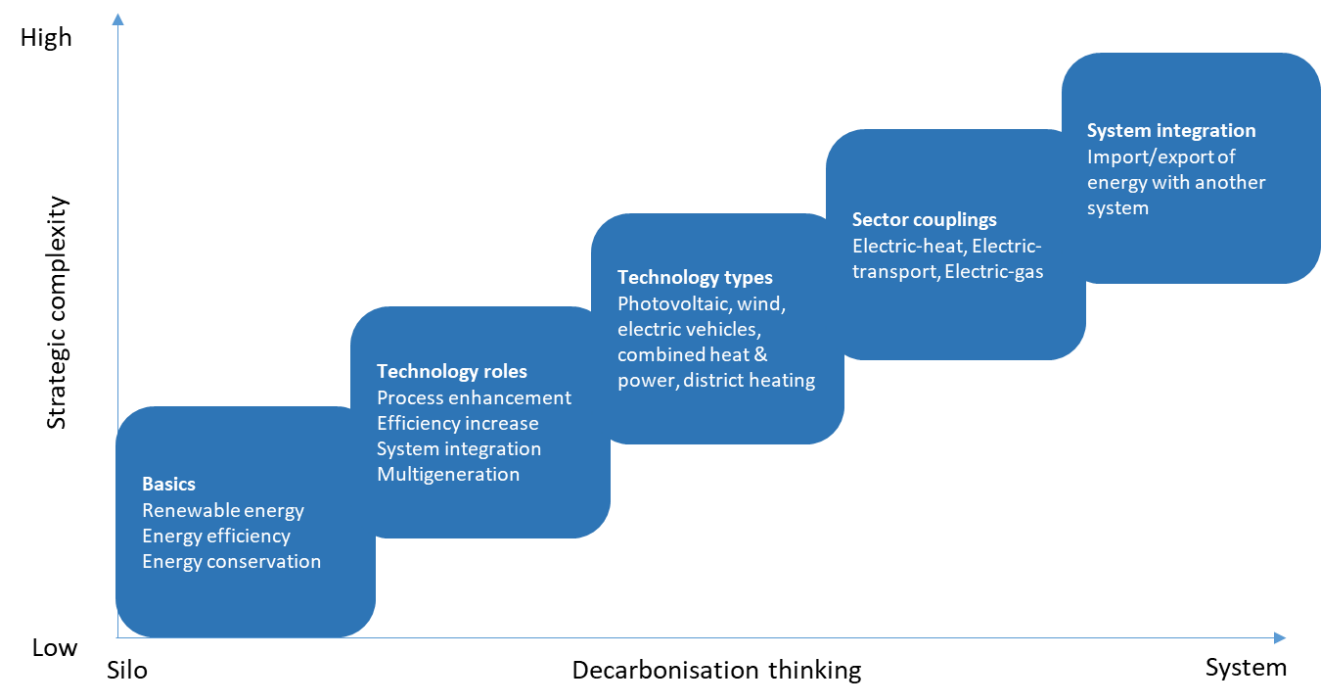

Figure 2. Relationship between increased decarbonisation thinking and strategic complexity.

As the strategic planning intensifies, the strategic complexity increases, and the decarbonisation thinking needs to shift towards system thinking. Often computer tools are required to help this $[19,45]$. The strategic thinking about system integration increases the likelihood of sustainable decarbonisation because the certainty around the system interconnection is better known and better planned.

Although some energy sectors can transition via technology replacement-e.g., light transport and EVs and efficient technologies in the electricity sector-several energy sectors pose a challenge to the transition. Including the heating sector [46-48], heavy transport [49,50], gas sector [26,51], and industry [51]. All require a mix of energy conservation, efficiency gains, renewable energy, and energy sector integration [52]. There is a risk of unsustainable outcomes if the energy system is not understood and planned with a detailed understanding of how to get to the long-term target. Including missed opportunities to integrate energy sectors, missed efficiency gains, overinvestments in infrastructure, 
unacceptable electricity demand costs, unsustainable biogenic resource consumption, and costly path dependency and lock-ins.

For long-term deep decarbonisation, cities need to strategically plan their technical energy transition from an energy system perspective as opposed to individual measures [23,53,54]. Three key analytical groups need to be considered and understood about the interconnected decarbonised system (Table 1): (1) essential elements [53,55]; (2) sustainability elements (economically, environmentally, socially) [43]; and (3) advanced energy system elements for an optimal energy system in the city and with surrounding regions $[55,56]$.

Table 1. Elements to consider for the energy system in the Vison strategy.

\begin{tabular}{|c|c|c|}
\hline Essential Elements & Sustainability Elements & Advanced System Elements \\
\hline $\begin{array}{ll}\text { - } & \text { Energy demands } \\
\text { - } & \text { The balance of all energy } \\
\text { - } & \text { Variety of resources and } \\
\text { - } & \text { Froduction technologies } \\
\text { - } & \text { Flexibility } \\
\text { - } & \text { Energy conservation needs } \\
\text { - } & \text { Grid affects } \\
\text { - } & \text { All sector-sector couplings } \\
\text { - } & \text { All grid interactions } \\
\text { - } & \text { Land use requirements } \\
\text { - } & \text { Resource demands } \\
\text { - } & \text { Economic costs } \\
\text { - } & \text { Region-to-region interaction }\end{array}$ & $\begin{array}{ll}\text { - } & \text { Exergetically sound } \\
\text { - } & \text { Energitically secure } \\
\text { - } & \text { Environmentally benign } \\
\text { - } & \text { Economically feasible } \\
\text { - } & \text { Commercially viable } \\
\text { - } & \text { Socially acceptable } \\
\text { - } & \text { Integrable } \\
\text { - } & \text { Reliable }\end{array}$ & $\begin{array}{ll}\text { - } & \text { Reserve capacity requirement } \\
\text { - } & \text { Use of import and export } \\
\text { energy, i.e., system } \\
\text { imbalances \& integratability } \\
\text { - } \quad \text { Island mode/connected } \\
\text { mode/or connected } \\
\text { island mode } \\
\text { - } \quad \text { Condensing mode operation } \\
\text { - } \quad \text { Primary energy } \\
\text { - } \quad \text { Renewablion/fuel use } \\
\text { - } \quad \text { Carbon dioxide emissions } \\
\text { - } \quad \text { Societal costs } \\
\text { - } \quad \text { Cost of energy/utility costs } \\
\text { - } \quad \text { Total resources spent } \\
\text { - } \quad \text { Short \& long-term } \\
\text { marginal costs }\end{array}$ \\
\hline
\end{tabular}

Numerous studies have investigated decarbonised energy systems within cities in this integrated way [53,57-59], although only from the technical energy system and not in terms of the strategic energy planning practices of the cities. Studies have paid little attention to the status of strategic vision and scenario creation and the integration process in cities. Numerous studies propose methods for analysing renewable regions based on rational strategic methods [53,60-62]. However, this article moves beyond these quantitative studies to understand and develop strategic thinking inside the city departments.

\subsubsection{The Role of Energy Visions and Scenarios}

Strategic visions and scenarios are needed to understand the interconnected energy system and the three groups of considerations. Therefore, the creation and integration of decarbonisation visions and scenarios in energy planning is a critical process and is a core part of energy planning practice and the vision strategy $[23,63]$. Both are usually interlinked. Qualitative descriptions communicate energy visions [63]. Examples of visions include "fossil-free by 2050" or "energy secure by 2050". Visions are usually not formed by using tools but created by the city authority, sometimes via stakeholder engagement in workshops.

Scenarios are a quantitative translation of the vision [63] and are important to define concrete actions and measures for implementation. Scenarios enable a city to make better planning decisions towards decarbonising their energy system, either by being able to understand what they need to do, communicate their plans better to other planners and stakeholders, and collaborate with other planners and stakeholders better. In general, scenarios are usually quantitative, and several tools can be selected 
to quantify and translate the values that meet the vision, including simulation, optimisation, and system dynamics tools [17]. There are also methods explicitly designed to mathematically translate from vision to scenario [63-65].

\subsection{Selection of Cities}

Ambitious cities were required for the study since they would be suitable beacons to determine where the current energy planning practice is at present. The collection is a stratified sample of the population of cities in Europe [66]. There are over 10,000 signatories in Covenant of Mayors, and over 6000 cities have developed a SEAP, meaning that many cities demonstrate this ambition. In this study, the aspiration was determined based on participation within the EU Horizon 2020 smart city lighthouse projects. The focus was on the projects within the "Smart Cities Information System" since this demonstrates ambition and progress [13]. Numerous projects focus on smart technologies, and only two projects have a specific focus on improving the integration of energy and urban planning. The cities were selected from these two projects and have been anonymised (Table 2 and Figure 3). Involvement in these projects indicates that the cities are either experienced with energy planning, have developed their methods, or are willing to advance their knowledge and planning approaches and have an expectation on how to proceed.

Table 2. City code, population, and representative interviewed.

\begin{tabular}{llll}
\hline & \multicolumn{1}{c}{ Population } & \multicolumn{1}{c}{ Person Interviewed } & \multicolumn{1}{c}{ Internal/External } \\
\hline City A & $<300,000$ & Engineer (planning department) & Internal \\
City B & $500,000-1,000,000$ & Group manager & Internal \\
City C & $500,000-1,000,000$ & Environmental investigator & Internal \\
City D & $<100,000$ & Project manager & External \\
City E & $<100,000$ & Consultant & External \\
City F & $<100,000$ & City planner & Internal \\
City G & $<100,000$ & Expert (in energy \& planning) & Internal/External \\
City H & $<300,000$ & Environmental technician & Internal \\
\hline
\end{tabular}

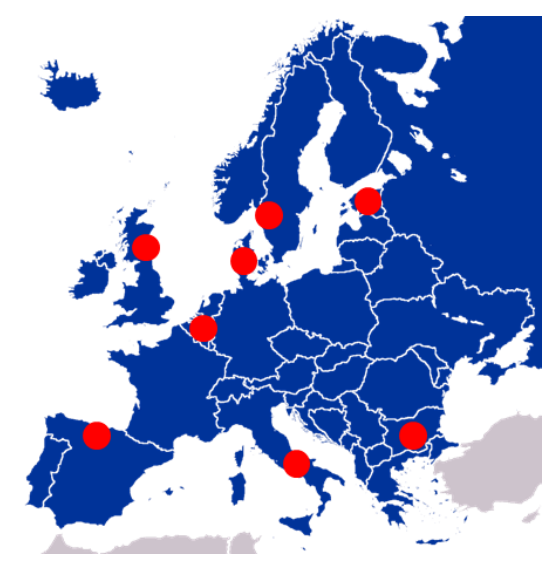

Figure 3. General location of the eight case cities in Europe.

Based on these two projects, eight cities were selected since they demonstrate ambition to become decarbonised and to practice energy planning. These cities began with SEAPs but graduated with individual methods. Urban planning in different countries will differ due to differing local conditions such as institutional and political arrangements, horizontally and vertically [30]. However, this analysis investigates the regime change at the strategic level, with the expectation that each country is the same strategically, although planning practices and geographical conditions may differ under the strategy. 


\subsection{Structure of Interviews}

Since energy planning is in its infancy and has not been insitutionalised yet, in most cities, it was not possible to find "energy planners" nor sometimes "planners" who worked on energy systems. However, the authors identified the most senior energy-related "planner" associated with the city. Sometimes located outside the city authority in an energy agency. They were identified based on their involvement, or coming involvement in plans related to energy such as a climate plan, energy plan, SEAP or similar. They were contacted and asked if they would do a semi-open phone interview to provide insight into their energy planning and scenario creation and integration process.

The authors carried out eight one-hour interviews (one from each of the eight cities). The authors collected and analysed relevant supplementary energy/climate plans to learn more about their energy planning. The authors carried out interviews from November 2018 to January 2019, and according to the themes of the analytical framework, were transcribed, coded, and categorised, allowing for analysis [67].

The authors believe that taking the view of a senior energy-related planner is sufficient for the article in this infancy phase. Furthermore, the small sample of interviews provides adequate insight for the research question since the cities offer broad coverage of Europe, including cities from the north, south, east, west, and central Europe. Also, the authors interviewed senior staff with detailed knowledge of the energy planning process as it is practiced today and will be in the future.

Although the main focus is on the Vision strategy, the interviews asked questions about all the elements for regime change, as described by [5] (Table 3). Since they are all relevant and interrelated in the (re)alignment of the regime, making the analysis more comprehensive.

Table 3. Themes informing the interview questions and analytical framework.

\begin{tabular}{lll}
\hline \multicolumn{1}{c}{ Theme } & \multicolumn{1}{c}{ Regime Element } & \multicolumn{1}{c}{ Insights } \\
\hline Energy planning arrangement & Institutions & $\begin{array}{l}\text { How the city does planning and energy } \\
\text { planning and who is involved }\end{array}$ \\
\hline Targets & Techniques & $\begin{array}{l}\text { Types of targets they have, the longevity } \\
\text { of the targets }\end{array}$ \\
\hline Stakeholder engagement & Actors & $\begin{array}{l}\text { Stakeholder engagement in the creation } \\
\text { of scenarios }\end{array}$ \\
\hline Energy scenarios \& technologies & Discourses \& Artefacts & $\begin{array}{l}\text { Creation and integration of scenarios in } \\
\text { energy planning and how stakeholders } \\
\text { involved, i.e., business, industry, } \\
\text { experts, citizens }\end{array}$ \\
\hline Plans & Discourses \& Artefacts & $\begin{array}{l}\text { Main urban plan and } \\
\text { energy-related plans }\end{array}$ \\
\hline
\end{tabular}

The authors also asked questions about: (1) the energy technologies for decarbonisation and their role in achieving the targets, and (2) the local conditions that affect energy planning, since these are essential elements in the complex energy system and provide further insights [28].

\subsection{Analytical Framework}

The results of the interviews were analysed using an analytical framework developed from the concept of "Strategic Energy Planning" (SEP) as described by [23]. Strategic Energy Planning is being used in Denmark by Danish municipalities to develop local strategic energy plans $[14,23,36]$, and has been evolving for the last decade and is still developing [36]. As renewable energy has increased in Denmark, it has required more "strategic" energy planning at the local level [54], since ongoing development of the energy system requires understanding the system in the future to plan for it.

The "strategic" aspects of SEP in Denmark is centred around the long-term target of $100 \%$ renewable energy system by 2050. Based on this target, it is necessary to create strategic energy visions 
and scenarios to understand the energy system in the future [23,54]. The visions and scenarios created towards this goal allow for energy system awareness over time, shifting away from silo- to systematic longitudinal- thinking. The strategy focuses on the final energy system; however, environmental conditions will change over time, meaning continuous development of scenario iterations towards the final energy system design (i.e., every couple of years). Meaning, a strategic element of SEP is the use and retention of scenarios because it allows for ongoing reflection and adjustments on the vision, energy system transition, and planning.

State authorities and researchers have developed long-term national goals and plans. However, there also needs to be a coordinated effort locally since the national level cannot do this alone $[54,68,69]$. Stakeholder engagement and collaboration are seen as necessary to achieve this complicated transition since stakeholders will need to develop some of the initiatives. Local and national governments need constant collaboration influenced by local needs, and scenarios can help achieve this [54]. Therefore, SEP also focuses on strategically aligning national and regional goals to coordinate national and local planning activities. If needed, cities can make micro-level strategies for neighbourhoods or districts based on the understanding of the holistic system of the whole city.

This advanced stage of renewable energy integration and energy planning practice in Denmark allows for using SEP as an analytical framework for the eight cities. The analytical framework applies several critical strategic elements in the analysis (Table 4). The authors analyse each city in terms of their strategic visions and scenario creation and integration process using these SEP elements.

Table 4. Core strategic elements for effective decarbonisation energy planning utilized in the analysis procedure.

\begin{tabular}{ll}
\hline \multicolumn{1}{c}{ Strategic Elements Used in the Analysis } & \multicolumn{1}{c}{ Description } \\
\hline $\begin{array}{l}\text { Decarbonisation target } \\
\text { Long term target }\end{array}$ & $\begin{array}{l}\text { Full decarbonisation of the entire energy system as opposed } \\
\text { to part } \\
\text { Medium-term target }\end{array}$ \\
$\begin{array}{l}\text { Informed target for the energy system and resource use } \\
\text { Informed by long term target }\end{array}$ \\
Consistent target & $\begin{array}{l}\text { Informed by long term and medium-term target } \\
\text { National to local coordination }\end{array}$ \\
Long term target does not change \\
Reflecting local changes against national goals \\
System awareness & $\begin{array}{l}\text { Whole energy system to allow for strategic technology } \\
\text { integration over time } \\
\text { Retention of scenarios }\end{array}$ \\
& $\begin{array}{l}\text { Role of technologies well understood within the system } \\
\text { Retaining scenarios which can be adjusted. Meaning all these } \\
\text { elements can be (re) understood if something changes. }\end{array}$ \\
\hline
\end{tabular}

\section{Results}

The results from the analysis are presented according to the core strategic elements in Table 4 and grouped into descriptive topics. The five topics dealing with the "targets" in Table 4 are dealt with together, as are the two topics "holistic system approach" and "system awareness".

\subsection{Consistent Long Term Decarbonisation Target: General Absence of Long-term Full Decarbonisation Targets}

Except for City A, who tentatively focuses on a long-term target-climate-neutral 2050-the other cities do not have a long-term target in mind (Table 5). Neutral means net zero emissions over one year. In City A, this target is an intention, and every plan reflects on this target; the city vision and climate plan integrates the target. The interviewee mention that Covenant of Mayors does not go far enough and has set a climate-neutral goal by 2050 to account for all emissions. 
Table 5. Final target year and decarbonisation target of each of the eight cities, and ideal strategic end target.

\begin{tabular}{|c|c|c|}
\hline & Description & Ideal Strategic End Target \\
\hline City A & Intention of climate-neutral 2050 & \multirow{8}{*}{$\begin{array}{c}\text { End year (i.e., 2050) complete } \\
\text { decarbonisation }\end{array}$} \\
\hline City B & $\begin{array}{l}\text { Politically stated } 2037 \text { carbon neutral. Likely follow } \\
\text { national government net-zero } 2045\end{array}$ & \\
\hline City C & 2050 sustainable and equitable $\mathrm{CO}_{2}$ level & \\
\hline City D & Will set a target for 2030 undecided for 2050 & \\
\hline City E & $40 \%$ of 2007 for 2030 , undecided for 2050 & \\
\hline City F & 2029 carbon neutral & \\
\hline City G & $40 \%$ reduction over 2010 by 2030 & \\
\hline City $\mathrm{H}$ & Undecided. Region target is $80 \%$ by 2050 & \\
\hline
\end{tabular}

City F has a goal of carbon neutrality by 2029 , determined by a group of stakeholders in 2007, which they see as an end-goal target. City F has no target beyond the carbon-neutral target of 2029, even though carbon neutrality involves exporting energy to offset local emissions, and the reality is that emissions remain after 2029.

Most cities have a medium-term target to 2030 for municipal, residential, industrial, and transport sectors based on the SEAP ambitions, or their planning cycle. Some cities have not set the target yet. For instance, City E makes a new plan every ten years, and the target often follows this. In their new plan, City E will determine the target based on a recalculation of the baseline in 2017 to understand the progress so far and understand the real reduction to 2030. City D is also undecided for 2030.

Most cities do not aim for complete decarbonisation and have explicit opinions about this. They see medium-term targets (2030) as incremental goals from which to make a new target when the time comes and do not mention in connection to longer-term scenario creation. City D sees long-term targets with high decarbonisation is not realistic since the aim should be incremental targets. If they cannot achieve them, then they cannot set a more ambitious target. They see targets as stepping-stones from which to set new targets when the time comes, rather than a way to plan towards the long term. City D specifically stated them as not necessary, and there is no reason to make them.

Some cities simply align with the region or country. For instance, City $\mathrm{H}$ will likely align with the regional government target of $80 \%$ reduction by 2050 . Furthermore, City B has set a carbon-neutral goal for 2037; however, the interviewee sees carbon-neutral as a political target and unrealistic and achieved with creative accounting. City B is in the process of making new targets and stated they are likely to follow the national government net-zero target by 2045. Although the interviewee of City B says that the EU $80 \%$ reduction by 2050 is very ambitious and before making these types of ambitious targets, they need to ensure it is achievable. They continue by saying they need to be careful when making strategy documents.

\subsection{National to Local Coordination: Soft Links from Local to National Goals}

All the cities have a connection to targets of other authorities but not always the national level (either national, regional, or other municipalities). For instance, in some cities, the national or regional level is not ambitious enough. For example, City A has Europe as a reference, not national or regional, since they are too slow and not ambitious enough. Also, City G is pushing the national level by having more ambitious targets along with the capital city.

A few cities follow national goals. City B tries to achieve national government goals in their local goals by aligning with the national government by focusing on sustainability, carbon reductions, and fuel poverty. City $\mathrm{C}$ link their climate program to regional and national goals. City $\mathrm{F}$ follows the 
national legislation about making commune plans, which contains a link with the national target. But not so much the EU.

City D collaborates with other municipalities and exchanges information and is in line with the goals and principles of surrounding municipalities. They are also part of the broader national framework and follow the national priorities and see how they fit with them. In general, they fit because they harmonize with the EU goals.

\subsection{Holistic, Systemic Approach and Systemic Awareness: Scenario Outcomes Informing Traditional Urban Planning Actions and Problems}

Cities D-H are moving beyond their SEAP 2020. They are following the Foresight method and are forecasting technology trends in their scenarios. The expected outcome from these scenarios is often similar in regards to understanding the effects of actions based on technology types, characteristics, and costs. For instance, City E sees the scenario foresight activity useful to give the possibility to identify and understand priorities and main action line strategies for the highly important but uncertain drivers of change, with the scenarios showing the drivers for future years. They will use scenarios to quantify the effects of actions. City F sees scenarios as a tool in the process of finding specific projects. City F quantitative scenarios partly inspired the commune plan with actions and have already taken scenario results and translated and integrated some actions into the commune plan.

City $G$ also stated that scenario results and objectives go hand in hand with action plans. They mention that action plans are separate but need to suggest actions that will support the objectives when working with stakeholders. City $\mathrm{G}$ expresses that these people usually use a very practical approach to planning and do not function from pure theoretical concepts of energy and climate policy. They want to see what exactly will happen; therefore, they say they always discuss feasible actions together with ambitious targets. City $\mathrm{G}$ will try to include more social translation and visualisations of scenario results.

City D sees scenarios as rooted in economic reasoning and a way to quantify and determine economic feasibility and $\mathrm{CO}_{2}$ reductions from energy measures to determine the measures. They use scenarios to optimize for economics, finding the optimal scenario in terms of achieving targets with optimum resources. City D does not see it as possible to ignore economics within the scenarios since private entities need to know the economics of projects. Furthermore, the scenarios show which measures and costs to include in the urban plan and from where the money comes. Although City D mentions that they see scenarios useful for setting up future targets, they base it on finding the most sensitive variables and most influential end results from which the largest impacts can come.

City B has shifted from a technology focus to a problem-based approach focusing on scenarios for particular problems they face or related to the EU projects in which they participate. City B has done numerous scenarios for numerous components of the energy system. For example, one project focused on EVs and the effect on the grid. City B is now developing a local heating and efficiency strategy in response to its energy poverty challenges.

City A stressed they are now at a point where they are always trying to make the step from vision to action as short as possible. City A did an energy scenario for the city using a consultancy. They are now focusing on districts and replicating one plan from one district to another; therefore, they used the scenario results to "zoom" into certain districts going into detail about thresholds and possibilities. They state that zooming into districts gives better insights to tackle challenges and make tailor-made actions for investors.

\subsubsection{Simple Scenario Calculations and External Support}

Based on the action-oriented scenarios, cities often focus on simple approaches, continue from previous activities, or simply leave quantification to external consultants.

City $G$ will utilize an Excel spreadsheet and use and modify calculations looking at several reductions and total $\mathrm{CO}_{2}$, based on assumptions for different scenarios. E.g., electricity reduction, 
recalculation of emissions from electricity. They also want an energy balance and flow chart of the city, with the primary sources of energy coming in and used inside the municipality.

City E is starting from SWOT analysis of the city and questionnaires (similar to the SEAP process and standard in the Foresight method), saying then they will have a useful input for scenario planning and the definition of main strategic actions.

In City D, new scenarios will build on the old ones and introduce the Foresight method, considering technical, economic, financial, administrative, legal, and administrative aspects. City D scenarios will investigate the achievements, what is the current status, and what are the different potential areas. They then look at what is economically feasible after choosing the potential actions in different areas and different technologies based on the previous plan.

City $\mathrm{H}$ will leave quantification up to a consulting company prescribing that they want impacts on $\mathrm{CO}_{2}$ quantified in the tender. City $\mathrm{H}$ will also hire a consultancy for developing the energy transition strategy. The consultancy develops the energy transition strategy from scenarios with budget and activities prioritized with estimated impacts. The strategy is used as the backbone of the system giving the timeline and roadmap over the next years for the city as a whole, integrating mobility, retrofitting, and renewable energies. The "energy centre" of the authority will assist and advise on the process and how to identify sector stakeholder activities and prepare the timeline and budget estimations with the consultancy help too.

City F also used external support for societal vision scenarios about the future to 2050, and detailed quantitative energy system scenarios for carbon neutral in 2029. Their detailed quantitative scenarios determined how the energy system would look when carbon neutral in 2029, and their qualitative scenarios looked into the future to start to think about how to act on that.

City B focus on specific problems leading them to focus on particular energy components. They work with external support for addressing different issues; for instance, they work with a University using modeling to understand impacts of energy efficiency on buildings, optimum charge and discharge efficiency of batteries concerning solar with the output being $\mathrm{CO}_{2}$ reductions.

Although some cities have made detailed decarbonisation studies, this has led to limited influence. For instance, City A has done detailed scenario work for the city, but the work emphasized biomass and therefore was not useful. However, they say it was helpful to have expert input, and they have utilised its detailed energy scenario to focus on districts.

City $C$ has a fossil-free 2050 investigation, kept active in planning circles; however, its climate program does not integrate it well. The investigation suggested dozens of measures in different areas, e.g., car traffic, buildings, cycling, walking, mass transit, energy efficiency, air traffic, renewable energy, renewable fuels, and so on. Broad measurements for each measure were quantified rather than specific, with measures evaluated on either having a minor, medium, or significant impact on climate emissions. The cost of each measure was also estimated, with an additional aim to quantify the time horizon for when the measure reaches full potential. However, this investigation has a limited influence on actual planning and decision making.

\subsubsection{Systemic Thinking versus Silo Thinking}

Cities are not speaking about systemic integration and interconnection of technologies in an energy system. Rather than placing the measure or action in an energy system context, typical answers from the cities focus on off-the-shelf silo thinking where they see solutions as being available, and the only issue is purchasing and implementation. Which is likely related to the focus on actions and simple approaches. For instance, some cities stated that all or some of the necessary technologies are already there, such as district heating or ICT (City H, City G). City G says that it is not a question of technology since new efficient technologies are on the market for all sectors. They see technology implementation as a critical challenge and only about replacing energy-efficient technologies.

Some cities emphasise only one energy sector. For instance, City $\mathrm{H}$ emphasise reducing and electrifying demands by focusing on high capacity electric transport and electric public transport (e.g., 
$100 \%$ electric busses and electric trams), and EVs. They state that batteries are necessary for renewable energy, and costs are decreasing, and this has a significant impact on the city.

Cities appear to focus on the elements they have influence over; for instance, cities often focus on municipally-owned assets, particularly buildings (standard in SEAPs). City E mentioned the installation of micro-wind systems in public buildings (e.g., schools), installation of PV panels in public buildings (e.g., schools), retrofitting in public buildings for energy efficiency purposes. Generally, the cities focus on energy efficiency (i.e., converting boilers to biomass (City D)), improving insulation and windows, integrating renewable energy (e.g., PV on rooftops during retrofitting (City H)).

Some cities don't know if it is essential to upscale or interconnect actions. City E is such a city; however, they mention that if going for $100 \%$ renewable in 2050, then they probably would shift from being a consumer to a producer of energy, so the focus should be on renewables and from waste, biogas, thus indicating some systemic thinking. Some systemic thinking is evident by City G saying that it is not just about technology; it is also about rearranging their processes to be more efficient and waste less. City $\mathrm{G}$ is looking at energy communities, collective production, collective ownership of energy production, and they say that if the aim is to develop PV or similar, then they need co-ops.

City D has a different concept of the energy system; they explain about systemic energy in terms of the building level, considering energy efficiency from insulation and windows, renewables on rooftops, and heat pumps.

City $\mathrm{F}$ took a systemic energy approach in their scenarios where they are focusing on integrating district heating, wind, solar thermal, solar PV, and biogas. They agreed to dozens of project proposals, and they developed an energy strategy to 2025 for $75 \%$ emission reductions. Despite the systemic scenario approach, the city authority of City F translated only some elements into the commune plan. The municipality abandoned the scenario since it served its purpose for the commune plan, however the external partner and stakeholders govern the holistic overview of the measures and technologies.

Some cities are implementing system integration technologies. For instance, City B is looking at ways to bring technologies together in a holistic approach using a smart grid and energy storage to maximize the local benefit from local innovation. A lot of work that City B does is about energy efficiency and heat decarbonisation, and they have implemented numerous technologies. Including ground source heat pumps, district heating islands in housing networks linked to gas $\mathrm{CHP}$, renewable solar and wind, and solar thermal. They are also starting to deploy heat pumps from the river and water source as an alternative to gas CHP.

\subsection{Retention of Scenarios: Extracting and Abandoning the Scenarios}

Often cities would mention abandoning the scenarios once obtaining the information. As mentioned above, City F has a systemic understanding of the energy system; however, the scenario is abandoned by the city authority since it has served its planning purpose. Although their external energy partner maintains the vision and scenario themselves. City D says once they know the economic feasibility, they abandon the scenario.

The detailed technical scenario of City A, carried out by a consultancy, was too biomass dependent. Although they want views and innovative ideas of consultants, the outcomes are always not entirely as they wanted, they do not get all the answers with surveys, and they do not take into account some aspects. They want to have more freedom and do not want prescriptive descriptions so detailed and so rigid, so they calculated their own. Once they extracted the technical scenario, they abandoned it, and now the focus is on districts from which they "copy and paste" onto other districts.

\section{Discussion}

The vision strategy includes long-term decarbonisation targets, holistic energy system thinking, and retention of scenarios. All the cities have carried out scenarios or are about to begin. However, the results demonstrated that cities do not make scenarios in light of the critical aspects of the vision strategy. Cities are doing scenarios for short-term targets and actions. Generally, the cities continue 
to focus on technology problem-solution, which leads to silo solutions and a focus on off-the-shelf thinking. This outcome is not surprising due to the low political appeal of long-term actions, and the appeal of immediate results [2]. Even in cities that analysed all aspects of the energy system, they often focus on actions, or they do not know how to use the results. Iyer and Edmonds [70] explain how this can be because there is missing information on how to interpret the results. For instance, in City C, although the study was sent to relevant departments and public companies and committees numerous times and revised, it has not been clear how to utilise the results, with measures poorly integrated into action plans. Furthermore, the involved stakeholders lack organisation. The planners have been asked to point to measures that should be taken but the investigation attempts to do this. In City F the detailed scenario was partly integrated into the commune plan but the planner says they only have about ten percent of their time to work on this and this is not their core task. Therefore only some aspects are integrated.

Typical targets are often short-term as opposed to long-term, so not strategic, and this reflects SEAP ambitions on a medium-term basis, usually to 2030. Lack of long-term targets is common in most European cities in their SEAPs [20]. Alternatively, urban planning processes dictate targets, e.g., every ten years in City E and City G. This means energy scenarios are not long-term. Short-term targets may influence the will to retain long-term systemic energy system scenarios, and means scenarios are often not retained by the city and discarded.

In most cities, it was not possible to find "energy planners" or planners who worked with energy systems. There was a mix of external and internal coordination, showing a lack of competences and indicating why the transition is happening at such a slow pace. Furthermore, an ongoing challenge is the power and influence of politicians who can influence how scenarios are being made and integrated into planning. The typical process is (1) visions, (2) scenarios, (3) actions, (4) plan, and then (5) approval of budgets by politicians. Often the scenarios are stunted to get adoption in the plan and approval. Scharpf ([71], p. 41) describes this outcome as "governance in the shadow of hierarchy". This outcome was evident, for instance, in City $\mathrm{H}$, where an external consultancy develops an energy transition strategy along with the "energy centre" and then propose this to the politicians. The politicians decide on the budget and choose projects and activities.

Furthermore, artefacts such as energy-related plans are often only supplementary, and this diminishes the role of scenarios since they will serve a part purpose within the final plan or energy-related plan. For instance, City A integrates its heat plan into its climate plan. City F integrates the energy plan into the commune plan. Once the integration is complete, they abandon their scenarios.

Some cities are just beginning their process and have limited awareness of the strategic level required. For instance, in City G, doing scenarios and making an integrated energy plan is a new territory and unique. They are challenging themselves to create something more open and more inclusive than the past. City G already sees the SEAP as an innovative approach; therefore, they will base their scenarios on their previous SEAP in 2015 and make something more radical for outcomes.

All the cities demonstrated a meta-governance type arrangement of horizontal and vertical urban and energy planning governance, involving citizens, interested organisations, and private interests in the scenarios finding solutions to local problems. The scenario process reveals the mutual impact of the actors, and consensus can be achieved [30]. This meta-governance enabling is usually the second governance technique [69]. It is evident in City E, for example. City E explains that scenarios create a possibility to put in place different stakeholders and also citizens and make clear to them the future development of energy and mobility. Stakeholders define the actions or a list of possible actions and validate the scenarios. City $\mathrm{H}$ uses scenarios as part of the preliminary strategy and to get feedback from stakeholders, where the data from feedback is useful for the strategic plan or energy transition strategy. They explain how citizens need to change certain things since they are primary energy consumers, and they see scenarios as important as a way to empower them to engage citizens in workshops and for people to feel the problem. 
There are indications of cities learning new strategic ways within their energy planning practices. In City A, of the numerous approaches they attempted (i.e., entire city analysis, transition management with arenas, district-level focus, backcasting), backcasting is seen as promising and enables them to see where they should be in 2040, 2030, 2020, and today. Backcasting is an essential method in the Vision strategy since it begins discourse about where the energy system should end [34,40]. Furthermore, backcasting creates awareness of choices [52]. For example, in City A, they look at options in the district zones based on backcasting, and this helps to stress urgency. City A mentions that the other approach with targets to five years or ten years is less ambitious, so they go the other way around discussing where they want to be in 2050 with numerous stakeholders. Back-casting was also used for the climate program of City C and in City F.

Furthermore, more advanced cities are seeing scenarios as becoming more beneficial over time and see the benefits of scenarios as they gain more experience. City B sees scenarios becoming more valuable as they get more data, thus increasing their ability to visualise and analyse data. Data can support the scenarios, and the cities can do them quickly to provide insights, and this gets better as the use of data gets better.

Based on this research, we present some recommendations for cities to help improve the Vision strategy in energy planning, along with selected useful references (Table 6).

Table 6. Summary of key lessons learned from the cities, aligned with suggested recommendations for the further development of energy planning practices in cities, including selected useful references.

\begin{tabular}{|c|c|}
\hline Key Lessons Learned & Suggested Recommendations and Useful References \\
\hline $\begin{array}{l}\text { Cities have a general absence of } \\
\text { long-term full decarbonisation targets }\end{array}$ & $\begin{array}{l}\text { - } \quad \text { Ensure to develop scenarios based on long-term end targets }[57,72-75] \\
\text { - } \quad \text { Ensure to develop long-term scenarios }[57,72,74,75]\end{array}$ \\
\hline $\begin{array}{l}\text { Cities have soft links from local to } \\
\text { national goals }\end{array}$ & $\begin{array}{l}\text { - Create scenarios in relation to long-term regional and national goals and } \\
\text { strategies [53-55] } \\
\text { - Communicate and understand the needs and interests of local actors } \\
\text { (i.e., strengthen the dialog with local actors) }[17,76,77]\end{array}$ \\
\hline $\begin{array}{l}\text { Cities rely on simple scenario } \\
\text { calculations and external support } \\
\text { using silo thinking as opposed to } \\
\text { system thinking }\end{array}$ & $\begin{array}{l}\text { - } \quad \text { Ensure to develop holistic energy system scenarios }[24,26] \\
\text { - } \quad \text { Avoid action-based silo thinking scenarios unless based on holistic scenarios } \\
\text { - } \quad \text { Reflect on the sustainability of the decarbonised energy system and the } \\
\text { advanced energy system considerations going into the future }[43,56]\end{array}$ \\
\hline $\begin{array}{l}\text { Cities use the scenario outcomes to } \\
\text { inform traditional urban planning } \\
\text { actions and problems }\end{array}$ & $\begin{array}{l}\text { - Utilise systematic scenarios for visualization, enriching visions, roadmap } \\
\text { creation, learning resource about the energy system and technologies }[46,79] \\
\text { Use scenarios to understand the scalability of technologies and } \\
\text { integration/interaction of technologies including a development timeline }[46,80] \\
\text { - Ensure scenarios are developed suitably useable for the energy planning } \\
\text { authorities }[76,77]\end{array}$ \\
\hline $\begin{array}{l}\text { Cities generally extract and abandon } \\
\text { the scenarios }\end{array}$ & $\begin{array}{l}\text { - See scenarios as servants providing information desired by the planner, rather } \\
\text { than serving as a guide to the planner (in which the planner can shape as } \\
\text { well) }[76,77] \\
\text { - } \quad \text { Retain long-term scenarios in the city authority and alter them over time }[23,54] \\
\text { - Strengthen the link between energy scenarios and energy plans }[10,79,81,82] \\
\text { - Reflect on high-level visions and make new scenario-informed visions }[63,77]\end{array}$ \\
\hline
\end{tabular}

\section{Conclusions}

This article aimed to evaluate the vision strategy in the energy planning of eight ambitious European cities. The main focus of the study was on how the cities create and integrate strategic visions and scenarios which are vital in the vision strategy of energy planning. The article evaluated the cities by applying an analytical framework of critical elements of SEP for $100 \%$ renewable systems. 
Strategic energy planning requires a long-term end decarbonisation target, holistic energy system thinking, and retention of scenarios. All cities demonstrate an ambition to achieve carbon reductions, and all include the ephemeral scenario development process in the energy planning arrangement, involving stakeholders and citizens in workshops. However, the cities are not approaching the vision strategy very effectively. The practice of energy planning is still often tied to the urban planning paradigm and traditions, and this limits the strategic energy planning requirements. Urban planning does not fit very well with energy planning and particularly not the vision strategy. The energy planning mostly focuses on shorter-term goals and actions, which are often in silos. Cities are not speaking about the systemic interconnection of technologies, and no city describes the integration of technologies in an energy system. Cities appear to focus on shorter-term targets and urban planning areas; for instance, often cities focus on municipally-owned assets or isolated off-the-shelf solutions. This self-governing is usually the first governance technique [69].

The cities do not yet show the needed competencies and ownership of energy system scenarios, which has consequences for making priorities and the overview of the different components and energy sectors in the energy system over time. Also, there is a mix of external and internal coordination, and there are some uncertainty and a methodological variety regarding making scenarios, which could lead to misaligned scenarios due to misinformed external partners.

There are promising signs and signs of a desire to break out, and through trial and error, some cities are making progress. But the results indicate that a level of understanding of the Vision strategy is still insufficient. For full, smart decarbonization, the energy scenarios of the cities need to change, and associated governance actors need to retain scenarios for ongoing revisions [19]. Even if not part of the urban plan, there needs to be a parallel way to ensure scenarios remain alive.

This article did not investigate the first and second strategic levels; however, further research should analyse how the vision strategy influences and integrates with these. Furthermore, research should focus on better exploitation of the vision strategy through understanding energy systems thinking in scenarios and the use and usefulness of scenarios. Research should ask why cities abandon scenarios and how they can be relevant (addressing simplicity, comprehension, useability, feasibility, ownership/control, value). The research could focus on collaborative approaches with cities to boost the vision strategy. On a policy level, the authors recommended strengthening the vision strategy by making SEP mandatory with a long term perspective (2050).

Author Contributions: D.M.-D. wrote the original draft of the article. L.K.J. and B.V.M. contributed with methodology input, review, comments, and validation of the paper. All authors have read and agreed to the published version of the manuscript.

Funding: The work was funded by the SmartEnCity project (grant number: 691883), which received funding from the H2020 programme of the European Commission.

Acknowledgments: The authors would like to thank the cities that participated in this research. The authors would also like to thank the three anonymous reviewers for their valuable insights.

Conflicts of Interest: The authors declare no conflict of interest. The funders had no role in the design of the study; in the collection, analyses, or interpretation of data; in the writing of the manuscript, and in the decision to publish the results.

\section{References}

1. 2050 Long-Term Strategy|Climate Action. Available online: https://ec.europa.eu/clima/policies/strategies/ 2050_en (accessed on 19 March 2020).

2. De Pascali, P.; Bagaini, A. Energy Transition and Urban Planning for Local Development. A Critical Review of the Evolution of Integrated Spatial and Energy Planning. Energies 2019, 12, 35. [CrossRef]

3. Mosannenzadeh, F.; Bisello, A.; Vaccaro, R.; D'Alonzo, V.; Hunter, G.W.; Vettorato, D. Smart Energy City Development: A Story Told by Urban Planners. Cities 2017, 64, 54-65. [CrossRef]

4. Bulkeley, H. Cities and the Governing of Climate Change. Annu. Rev. Environ. Resour. 2010, 35, $229-253$. [CrossRef] 
5. Bulkeley, H.; Castán Broto, V.; Maassen, A. Low-Carbon Transitions and the Reconfiguration of Urban Infrastructure. Urban Stud. 2014, 51, 1471-1486. [CrossRef]

6. Wejs, A. Integrating Climate Change into Governance at the Municipal Scale: An Institutional Perspective on Practices in Denmark. Environ. Plan. C Gov. Policy 2014, 32, 1017-1035. [CrossRef]

7. Reckien, D.; Salvia, M.; Heidrich, O.; Church, J.M.; Pietrapertosa, F.; De Gregorio-Hurtado, S.; D'Alonzo, V.; Foley, A.; Simoes, S.G.; Lorencová, E.K.; et al. How Are Cities Planning to Respond to Climate Change? Assessment of Local Climate Plans from 885 Cities in the EU-28. J. Clean. Prod. 2018, 191, 207-219. [CrossRef]

8. Thery, R.; Zarate, P. Energy Planning: A Multi-Level and Multicriteria Decision Making Structure Proposal. Cent. Eur. J. Oper. Res. 2009, 17, 265-274. [CrossRef]

9. Cajot, S.; Peter, M.; Bahu, J.-M.; Koch, A.; Maréchal, F. Energy Planning in the Urban Context: Challenges and Perspectives. Energy Procedia 2015, 78, 3366-3371. [CrossRef]

10. Cajot, S.; Peter, M.; Bahu, J.-M.; Guignet, F.; Koch, A.; Maréchal, F. Obstacles in Energy Planning at the Urban Scale. Sustain. Cities Soc. 2017, 30, 223-236. [CrossRef]

11. REN21. REN21-2019 Global Status Report; REN21: Paris, France, 2019.

12. Gordon, D.J.; Johnson, C.A. City-Networks, Global Climate Governance, and the Road to $1.5^{\circ}$ C. Curr. Opin. Environ. Sustain. 2018, 30, 35-41. [CrossRef]

13. EC-Funded Projects Tracked by the Smart Cities Information System / Smartcities Information System. Available online: https://smartcities-infosystem.eu/sites-projects/projects (accessed on 30 March 2020).

14. Krog, L. How Municipalities Act under the New Paradigm for Energy Planning. Sustain. Cities Soc. $2019,47$. [CrossRef]

15. Hansen, K.; Breyer, C.; Lund, H. Status and Perspectives on 100\% Renewable Energy Systems. Energy 2019, 175, 471-480. [CrossRef]

16. Assoumou, E.; Marmorat, J.P.; Roy, V. Investigating Long-Term Energy and CO2 Mitigation Options at City Scale: A Technical Analysis for the City of Bologna. Energy 2015, 92, 592-611. [CrossRef]

17. Mirakyan, A.; De Guio, R. Integrated Energy Planning in Cities and Territories: A Review of Methods and Tools. Renew. Sustain. Energy Rev. 2013, 22, 289-297. [CrossRef]

18. Nuorkivi, A.; Anna-Maija-Ahonen. Urban Planners With Renewable Energy Skills Training Description. Tema J. L. Use Mobil. Environ. 2013, 6, 159-170.

19. Steidle, T.; Schlenzig, C.; Cuomo, V.; Macchiato, M.; Lavagno, E.; Rydèn, B.; Willemsen, S.; Grevers, W. Advanced Local Energy Planning, a Guidebook. IEA-BCS Annex 33. 2000, p. 206, IEA Energy Technology Systems Analysis Program (ETSAP). Available online: https://iea-etsap.org/index.php/applications/local (accessed on 22 January 2020).

20. Kona, A.; Bertoldi, P.; Monforti-Ferrario, F.; Rivas, S.; Dallemand, J.F. Covenant of Mayors Signatories Leading the Way towards 1.5 Degree Global Warming Pathway. Sustain. Cities Soc. 2018, 41, 568-575. [CrossRef]

21. Croci, E.; Lucchitta, B.; Janssens-Maenhout, G.; Martelli, S.; Molteni, T. Urban CO2 Mitigation Strategies under the Covenant of Mayors: An Assessment of 124 European Cities. J. Clean. Prod. 2017, 169, 161-177. [CrossRef]

22. Bertoldi, P.; Bornas, C.D.; Monni, S.; Piers De Raveschoot, R. How to Develop a Sustainable Energy Action Plan (SEAP)—Guidebook; Publications Office of the European Union: Luxembourg, Luxembourg, 2010; p. 120, Covenant of Mayors for Climate and Energy; Available online: https://www.eumayors.eu/IMG/pdf/seap_ guidelines_en.pdf (accessed on 22 January 2020).

23. Krog, L.; Sperling, K. A Comprehensive Framework for Strategic Energy Planning Based on Danish and International Insights. Energy Strateg. Rev. 2019, 24, 83-93. [CrossRef]

24. Lund, H.; Østergaard, P.A.; Connolly, D.; Mathiesen, B.V. Smart Energy and Smart Energy Systems. Energy 2017, 137, 556-565. [CrossRef]

25. Mathiesen, B.V.; Lund, H.; Connolly, D. Limiting Biomass Consumption for Heating in 100\% Renewable Energy Systems. Energy 2012, 48, 160-168. [CrossRef]

26. Mathiesen, B.V.; Lund, H.; Connolly, D.; Wenzel, H.; Østergaard, P.A.; Möller, B.; Nielsen, S.; Ridjan, I.; Karnøe, P.; Sperling, K.; et al. Smart Energy Systems for Coherent 100\% Renewable Energy and Transport Solutions. Appl. Energy 2015, 145, 139-154. [CrossRef]

27. Drysdale, D.; Mathiesen, B.V.B.V.; Paardekooper, S. Transitioning to a 100\% Renewable Energy System in Denmark by 2050: Assessing the Impact from Expanding the Building Stock at the Same Time. Energy Effic. 2018, 12, 37-55. [CrossRef] 
28. Bale, C.S.E.; Varga, L.; Foxon, T.J. Energy and Complexity: New Ways Forward. Appl. Energy 2015, 138. [CrossRef]

29. Williams, P.M. Community Strategies: Mainstreaming Sustainable Development and Strategic Planning? Sustain. Dev. 2002, 10, 197-205. [CrossRef]

30. Sehested, K. Urban Planners as Network Managers and Metagovernors. Plan. Theory Pract. 2009, 10, $245-263$. [CrossRef]

31. Monstadt, J. Conceptualizing the Political Ecology of Urban Infrastructures: Insights from Technology and Urban Studies. Environ. Plan. A 2009, 41, 1924-1942. [CrossRef]

32. Berke, P.R.; Conroy, M.M. Are We Planning for Sustainable Development? An Evaluation of 30 Comprehensive Plans. J. Am. Plan. Assoc. 2000, 66, 21-33. [CrossRef]

33. Veeman, T.S.; Politylo, J. The Role of Institutions and Policy in Enhancing Sustainable Development and Conserving Natural Capital. Environ. Dev. Sustain. 2003, 5, 317-332. [CrossRef]

34. Bagheri, A.; Hjorth, P. Planning for Sustainable Development: A Paradigm Shift Towards a Process-Based Approach. Sustain. Dev. 2007, 15, 83-96. [CrossRef]

35. Beatley, T.; Manning, K. The Ecology of Place: Planning for Environment, Economy, and Community; Island Press: Washington, DC, USA, 1997.

36. Petersen, J.-P. The Application of Municipal Renewable Energy Policies at Community Level in Denmark: A Taxonomy of Implementation Challenges. Sustain. Cities Soc. 2018, 38, 205-218. [CrossRef]

37. Larsen, S.V.; Kørnøv, L.; Wejs, A. Mind the Gap in SEA: An Institutional Perspective on Why Assessment of Synergies amongst Climate Change Mitigation, Adaptation and Other Policy Areas Are Missing. Environ. Impact Assess. Rev. 2012, 33, 32-40. [CrossRef]

38. Cajot, S.; Mirakyan, A.; Koch, A.; Maréchal, F. Multicriteria Decisions in Urban Energy System Planning: A Review. Front. Energy Res. 2017, 5. [CrossRef]

39. Webb, J.; Hawkey, D.; Tingey, M. Governing Cities for Sustainable Energy: The UK Case. Cities 2016, 54, 28-35. [CrossRef]

40. Höjer, M.; Gullberg, A.; Pettersson, R. Backcasting Images of the Future City-Time and Space for Sustainable Development in Stockholm. Technol. Forecast. Soc. Change 2011, 78, 819-834. [CrossRef]

41. Bale, C.S.E.; Foxon, T.J.; Hannon, M.J.; Gale, W.F. Strategic Energy Planning within Local Authorities in the UK: A Study of the City of Leeds. Spec. Sect. Front. Sustain. 2012, 48, 242-251. [CrossRef]

42. Lund, H.; Andersen, A.N.; Østergaard, P.A.; Mathiesen, B.V.; Connolly, D. From Electricity Smart Grids to Smart Energy Systems-A Market Operation Based Approach and Understanding. Energy 2012, 42, 96-102. [CrossRef]

43. Dincer, I.; Acar, C. Smart Energy Systems for a Sustainable Future. Appl. Energy 2017, 194, 1-11. [CrossRef]

44. Gram-Hanssen, K. Efficient Technologies or User Behaviour, Which Is the More Important When Reducing Households' Energy Consumption? Energy Effic. 2013, 6, 447-457. [CrossRef]

45. Keirstead, J.; Jennings, M.; Sivakumar, A. A Review of Urban Energy System Models: Approaches, Challenges and Opportunities. Renew. Sustain. Energy Rev. 2012, 16, 3847-3866. [CrossRef]

46. Connolly, D.; Lund, H.; Mathiesen, B.V.; Werner, S.; Möller, B.; Persson, U.; Boermans, T.; Trier, D.; Østergaard, P.A.; Nielsen, S. Heat Roadmap Europe: Combining District Heating with Heat Savings to Decarbonise the EU Energy System. Energy Policy 2014, 65, 475-489. [CrossRef]

47. Möller, B.; Wiechers, E.; Persson, U.; Grundahl, L.; Lund, R.S.; Mathiesen, B.V. Heat Roadmap Europe: Towards EU-Wide, Local Heat Supply Strategies. Energy 2019, 177, 554-564. [CrossRef]

48. Persson, U.; Möller, B.; Werner, S. Heat Roadmap Europe: Identifying Strategic Heat Synergy Regions. Energy Policy 2014, 74, 663-681. [CrossRef]

49. Connolly, D.; Mathiesen, B.V.; Ridjan, I. A Comparison between Renewable Transport Fuels That Can Supplement or Replace Biofuels in a 100\% Renewable Energy System. Energy 2014, 73, 110-125. [CrossRef]

50. Ridjan, I.; Mathiesen, B.V.; Connolly, D.; Duić, N. The Feasibility of Synthetic Fuels in Renewable Energy Systems. Energy 2013, 57, 76-84. [CrossRef]

51. Korberg, A.D.; Skov, I.R.; Mathiesen, B.V. The Role of Biogas and Biogas-Derived Fuels in a 100\% Renewable Energy System in Denmark. Energy 2020, 199, 117426. [CrossRef]

52. Lund, H. Renewable Energy Systems-A Smart Energy Systems Approach to the Choice and Modelling of $100 \%$ Renewable Solutions, 2nd ed.; Academic Press: Cambridge, MA, USA, 2014. 
53. Drysdale, D.; Mathiesen, B.V.; Lund, H. From Carbon Calculators to Energy System Analysis in Cities. Energies 2019, 12. [CrossRef]

54. Sperling, K.; Hvelplund, F.; Mathiesen, B.V. Centralisation and Decentralisation in Strategic Municipal Energy Planning in Denmark. Energy Policy 2011, 39, 1338-1351. [CrossRef]

55. Thellufsen, J.Z.; Lund, H. Roles of Local and National Energy Systems in the Integration of Renewable Energy. Appl. Energy 2016, 183, 419-429. [CrossRef]

56. Østergaard, P.A. Reviewing Optimisation Criteria for Energy Systems Analyses of Renewable Energy Integration. Energy 2009, 34, 1236-1245. [CrossRef]

57. Bačeković, I.; Østergaard, P.A. A Smart Energy System Approach vs a Non-Integrated Renewable Energy System Approach to Designing a Future Energy System in Zagreb. Energy 2018, 155, 824-837. [CrossRef]

58. Alberg Østergaard, P.; Mathiesen, B.V.; Möller, B.; Lund, H. A Renewable Energy Scenario for Aalborg Municipality Based on Low-Temperature Geothermal Heat, Wind Power and Biomass. Energy 2010, 35, 4892-4901. [CrossRef]

59. Østergaard, P.A.; Lund, H. A Renewable Energy System in Frederikshavn Using Low-Temperature Geothermal Energy for District Heating. Appl. Energy 2011, 88, 479-487. [CrossRef]

60. Mourmouris, J.C.; Potolias, C. A Multi-Criteria Methodology for Energy Planning and Developing Renewable Energy Sources at a Regional Level: A Case Study Thassos, Greece. Energy Policy 2013, 52, 522-530. [CrossRef]

61. Xydis, G. Development of an Integrated Methodology for the Energy Needs of a Major Urban City: The Case Study of Athens, Greece. Renew. Sustain. Energy Rev. 2012, 16, 6705-6716. [CrossRef]

62. Cormio, C.; Dicorato, M.; Minoia, A.; Trovato, M. A Regional Energy Planning Methodology Including Renewable Energy Sources and Environmental Constraints. Renew. Sustain. Energy Rev. 2003, 7, 99-130. [CrossRef]

63. Trutnevyte, E. The Allure of Energy Visions: Are Some Visions Better than Others $\alpha$. Energy Strateg. Rev. 2014, 2, 211-219. [CrossRef]

64. Trutnevyte, E.; Stauffacher, M.; Scholz, R.W. Supporting Energy Initiatives in Small Communities by Linking Visions with Energy Scenarios and Multi-Criteria Assessment. Energy Policy 2011, 39, 7884-7895. [CrossRef]

65. Trutnevyte, E.; Stauffacher, M.; Scholz, R.W. Linking Stakeholder Visions with Resource Allocation Scenarios and Multi-Criteria Assessment. Eur. J. Oper. Res. 2012, 219, 762-772. [CrossRef]

66. Flyvbjerg, B. Five Misunderstandings about Case-Study Research. Qual. Inq. 2006, 219-245. [CrossRef]

67. Erlingsson, C.; Brysiewicz, P. A Hands-on Guide to Doing Content Analysis. Afr. J. Emerg. Med. 2017, 7, 93-99. [CrossRef]

68. Thellufsen, J.Z.; Lund, H. Cross-Border versus Cross-Sector Interconnectivity in Renewable Energy Systems. Energy 2017, 124, 492-501. [CrossRef]

69. Lo, K. Urban Carbon Governance and the Transition toward Low-Carbon Urbanism: Review of a Global Phenomenon. Carbon Manag. 2014, 5, 269-283. [CrossRef]

70. Iyer, G.; Edmonds, J. Interpreting Energy Scenarios. Nat. Energy 2018, 3, 357-358. [CrossRef]

71. Scharpf, F.W. Games Real Actors Could Play: Positive and Negative Coordination in Embedded Negotiations. J. Theor. Polit. 1994, 6, 27-53. [CrossRef]

72. Phdungsilp, A. Futures Studies' Backcasting Method Used for Strategic Sustainable City Planning. Futures 2011, 43, 707-714. [CrossRef]

73. Leal, V.M.S.; Azevedo, I. Setting Targets for Local Energy Planning: Critical Assessment and a New Approach. Sustain. Cities Soc. 2016, 26, 421-428. [CrossRef]

74. Lund, H.; Mathiesen, B.V. Energy System Analysis of 100\% Renewable Energy Systems-The Case of Denmark in Years 2030 and 2050. Energy 2009, 34, 524-531. [CrossRef]

75. Ć́osić, B.; Krajačić, G.; Duić, N. A 100\% Renewable Energy System in the Year 2050: The Case of Macedonia. Energy 2012, 48, 80-87. [CrossRef]

76. van Sluisveld, M.A.E.; Hof, A.F.; Carrara, S.; Geels, F.W.; Nilsson, M.; Rogge, K.; Turnheim, B.; van Vuuren, D.P. Aligning Integrated Assessment Modelling with Socio-Technical Transition Insights: An Application to Low-Carbon Energy Scenario Analysis in Europe. Technol. Forecast. Soc. Change 2020, 151, doi. [CrossRef]

77. Geels, F.W.; McMeekin, A.; Pfluger, B. Socio-Technical Scenarios as a Methodological Tool to Explore Social and Political Feasibility in Low-Carbon Transitions: Bridging Computer Models and the Multi-Level Perspective in UK Electricity Generation (2010-2050). Technol. Forecast. Soc. Change 2020, 151, 119258. [CrossRef] 
78. Lund, H.; Möller, B.; Mathiesen, B.V.; Dyrelund, A. The Role of District Heating in Future Renewable Energy Systems. Energy 2010, 35, 1381-1390. [CrossRef]

79. Mathiesen, B.V.; Lund, H.; Karlsson, K. 100\% Renewable Energy Systems, Climate Mitigation and Economic Growth. Appl. Energy 2011, 88, 488-501. [CrossRef]

80. Hansen, K.; Connolly, D.; Lund, H.; Drysdale, D.; Thellufsen, J.Z.J.Z. Heat Roadmap Europe: Identifying the Balance between Saving Heat and Supplying Heat. Energy 2016, 115, 1663-1671. [CrossRef]

81. Lund, H.; Sorknæs, P.; Mathiesen, B.V.; Hansen, K. Beyond Sensitivity Analysis: A Methodology to Handle Fuel and Electricity Prices When Designing Energy Scenarios. Energy Res. Soc. Sci. 2018, 39, 108-116. [CrossRef]

82. Sperling, K. How does a pioneer community energy project succeed in practice? The case of the Samsø Renewable Energy Island. Ren. and Sus. Ene. Rev. 2017, 71, 884-897. [CrossRef]

(C) 2020 by the authors. Licensee MDPI, Basel, Switzerland. This article is an open access article distributed under the terms and conditions of the Creative Commons Attribution (CC BY) license (http://creativecommons.org/licenses/by/4.0/). 